\title{
Practical Scenario of Implementation of the Children Act, 2013 in Sylhet Metropolitan Area and Rule of Law
}

\author{
Md. Jahurul Islam ${ }^{1}$, Md. Arifuzzaman ${ }^{2 *}$, and Juber Ahmmod Khan ${ }^{3}$ \\ ${ }^{1}$ Department of Law, Khwaja Yunus Ali University, Sirajganj, Bangladesh; ${ }^{2}$ Department of Law, Green University of \\ Bangladesh, Dhaka, Bangladesh; and ${ }^{3}$ North East University, Sylhet, Bangladesh. \\ *Correspondence: arif@law.green.edu.bd (Dr. Md. Arifuzzaman, Assistant Professor, Dept. of Law, Green University of \\ Bangladesh, Dhaka, Bangladesh).
}

\begin{abstract}
According to section 96 of the Children Act, 2013 "the Government shall take all necessary measures for the effective implementation of this Act and may, if necessary, issue directions in this regard". That means Bangladesh has to take essential steps regarding implementation of the Children Act, 2013 under its territory including Sylhet Metropolitan Area. To ensure protection of the best interest of the child and application of rule of law in this Sylhet Metropolitan Area the Government of Bangladesh shall try to its best. If in that mentioned area does not get implementation of this said Act the Government cannot say they are able to establish rule of law whole over the Bangladesh. Main objective of this study is to highlight the current situation of implementation of the Children Act, 2013 in Sylhet Metropolitan Area. This study provides suggestions to the Government, which steps are necessary to take for the effective implementation of the mentioned Act in Sylhet Metropolitan Area. Secondary and primary data used in the research are based on fieldwork in different child related institutions (Probation Officers Office, Police Station, Metropolitan Children's Court, Sharkari Shishu Paribar, Chotomoni Nibash, Safe Home, Victim Support Centre, and Development Fair 2018).
\end{abstract}

Keywords: Kidnapped children, Raped girl, Child affairs police, and Metropolitan children's court.

\section{INTRODUCTION:}

Convention on the Rights of the Child (CRC) is considered a universal convention as nearly every country of the world has signed the convention excepting USA. The Children Act, 2013 reflects the provisions of the Convention on the Rights of the Child (CRC).

It seems some provisions have been incorporated in response to directions of the Supreme Court as well as the requirements of other international instruments such as the Beijing Rules. Child protection is the protection of children from violence, exploitation, abuse and neglect. For protecting the rights of the child that the Children Act, 2013 need to proper implementation (Islam, 2020).
If that the Act gets proper implementation children be protected in and out of the home. If that the Act gets proper implementation girls and boys will be protected from violations such as abuse, sexual exploitation, trafficking and work in hazardous conditions, as well as harmful practices, including child marriage.

\section{METHODOLOGY:}

This report is based on fieldwork and this paper is also based on secondary data collected from the United Nations Convention on the Rights of the Child, text books, journals, newspapers, and websites. After the collection of data, the collected data were tabulated on the Table. Then, the recommenddations have been made at the end of the report. 


\section{Objectives of the study}

1) To review the implementation status of the Children Act, 2013.

2) To increase respect for the human rights of children.

3) To established the Metropolitan Child Welfare Board and Child Develop Centre.

4) To find out the actual causes behind problems.

5) To highlight defects in the existing procedural law.

6) To find out what should be the role of judges, lawyers, Child Affairs Police Officers Probation Officers, etc.

7) To provide possible suggestions to mitigate the challenges.

\section{Definition of Child}

Section 4 of the Children Act, 2013 says that all persons up to age of 18 years shall be regarded as children for the purposes of this Act. According to Article 1of UNCRC "a child means every human being below the age of eighteen years unless under the law applicable to the child, majority is attained earlier".

\section{Background of the Children Act, 2013}

The Child Bill 2013, passed on June 16, 2013 by the national parliament was published through a gazette notification on June 20. The new Act is harmonized with the United Nation Convention on the Rights of the Child (CRC) and has referred to the CRC in the preamble and replaced the Child Act, 1974. The Children Act, 2013 is drafted by the ministry of Social Welfare and consists of 11 chapters and 100 sections. The Children Act, 2013, officially known as "Shishu Ain, 2013". By a subsequent Gazette notification dated 18 August, 2013 the Act was made effective from 21 August, 2013.

\section{Rule of Law}

One of the basic principles of the English constitution is the rule of law. This doctrine is also accepted in the constitution of Bangladesh. The rule of law is currently is one of the most discussed matters of developing countries. Developed countries and donor agencies all the time advise the developing countries for good governance and sustainable development. Actually good governance and sustainable development generally be governed by the proper application of rule of law. One of the major objects of making laws is to preserve law and order in society, a peaceful environment for the advancement of the people. In true and real sense there is lack in rule of law in Bangladesh today. Law in Bangladesh follows a course of discerning and discretionary application. Institution and procedures essential for ensuring rule of law are also not effective in the country.

\section{Child Rights}

All rights spelled out by the Universal Declaration on human rights. "Children's rights are the human rights of children with particular attention to the rights of special protection and care afforded to minors". Bangladesh constitution also guaranteed some rights for children. Other definitions include the rights to care and nurturing (Ali, 2013; Islam, 2015). There are no definitions of other terms used to describe young people such as "adolescents", "teenagers", or "youth" in international law, but the children's rights movement is considered distinct from the youth rights movement. The field of children's rights extents the fields of law, politics, religion, and morality. Children rights take account of their right to association with both parents, human identity as well (Mohajan, 2014; Banks, 2007) as the basic needs for physical protection, food, health care, universal state paid education and criminal laws appropriate for the age and development of the child, equal protection of the child civil rights and freedom from discrimination on the basis of the child race, gender, sexual orientation, gender identity, national origin, religion, disability, colour, ethnicity or other characteristics (Ashrafuzzaman, 2014; Pare, 2003). Children have two types of human rights under international human rights law (White, 2002; Blanchet, 2001). Firstly, they have the same fundamental general human rights as adults, though some human rights such as the right to marry are dormant until they are of age. Secondly, they have special human rights that are necessary to protect them during their minority (Mamun et al., 2008; Ehsan, 2001).

\section{Child Labour in Sylhet Metropolitan Area}

Section 34, Sub-Section 1 of the Bangladesh Labour Code, 2006 says that "no child can be employed to work in any trade or in any establishment". Child Labour is a common phenomenon in all Upazila, District, Metropolitan Area and others areas in Bangladesh. Sylhet Metropolitan City is no exception. In Sylhet Metropolitan Area huge numbers of children are engaged as child labourers mostly in hazardous 
and exploitative conditions in the informal economy. Employers appoint children due to cheap labour and exploit them due to their being unskilled. By employing children on very law wages, employers try to maximize their profits. In many cases, parents request employers to employ their children. In Sylhet Metropolitan Area many child work in house, construction, garage, etc. Children are engaged with much hazardous work in Sylhet Metropolitan Area.

Proportion of Real Child Worker (10-14 Years) in 2011 (Source: Child Equity Atlas: Pockets of Social Deprivation in Bangladesh, July 2013, BBS, UNICEF, BIDS).

\begin{tabular}{|c|c|c|c|}
\hline Division & Both Sex & Male & Female \\
\hline Barisal & 4.4 & 7.4 & 1.2 \\
\hline Chittagong & 5.3 & 8.2 & 2.2 \\
\hline Dhaka & 8.0 & 11.0 & 4.8 \\
\hline Khulna & 3.7 & 6.5 & 0.7 \\
\hline Rajshahi & 5.0 & 8.6 & 1.0 \\
\hline Rangpur & 4.5 & 7.5 & 1.2 \\
\hline Sylhet & 7.5 & 12.6 & 2.0 \\
\hline
\end{tabular}

This data shows that after Chittagong Sylhet is on 2nd position in case of proportion of real child worker (years 10-14) among all of the Division.

\section{Child Victimization in Sylhet Metropolitan Area}

The world Health Organization refers to child victimization as child abuse and neglect which includes all forms of physical and emotional ill treatment, sexual abuse, neglect and exploitation that results in actual or potential harm to the child's health, development or dignity (Ferdousi, 2014; Islam, 2012). Children may be victimized by family members, by friends, by other children and by strangers etc. It is very common in Sylhet Metropolitan Area. Children are used to begging in front of the mosque gate and other places the number of which is also increasing day by day. Street children are deprived from their rights such as right to food, right to shelter, right to education and other rights. Children suffer victimization because of broken family. Every broken family has many problems which affects directly to the children. "Addicted children are also victim. Addicted children frequently involve in various criminal activities and criminal association to manage drugs. Sometimes they commit fatal offenses when they are in addicted situation. Girl children are facing harassment by boys in school, college and other places. They face the situation of eve teasing. In Sylhet Metropolitan Area, many guardians of boys lives in abroad. So, boys enjoy very much freedom. As a result, they make eve teasing against girl children. Worker child is suffered physical and mental torture in the workplace. Sometimes worker children suffer sexual abuse when engaged in house hold service. In that area, senior groups often oppress juniors in various situation by bullying and pinching, such as in residential school system, which produces scope of child victimization. In that city children suffer physical and mental pain because of coaching system after end of school. One of the best example of child victimization occurred On July 8, 2015. Rajon was beaten to death by a group of brutes in Kumargaon Bus Stand area of Sylhet Sadar allegedly for trying to steal a rickshaw van.

\section{Kidnapped Children in Sylhet}

Section 2 of the Nari O Shishu Nirjaton Damun Ain, 2000 lays down a provision about the definition of kidnapping, "Kidnapping means compelling any person to go from one place to another by force or inducement or enticement or intimidation". Kidnapping is an illegal act. Kidnapping may be done to demand for ransom in exchange for releasing the victim or for other illegal purposes. In Sylhet Division including Sylhet Metropolitan Area kidnapping children is one of the major problems. Sometimes news has been published by the newspaper about the incident of child kidnapping. The following data indicate the real phenomenon.

Total kidnapped children in Sylhet Division in 2013 to August 2018 (Source: Victim Support Centre Kotwali Model Police Station S M P Sylhet)

\begin{tabular}{|c|c|}
\hline Year & Kidnapped Child \\
\hline 2013 & 4 \\
\hline 2014 & 12 \\
\hline 2015 & 35 \\
\hline 2016 & 22 \\
\hline 2017 & 32 \\
\hline 2018 & 21 \\
\hline Total & 126 \\
\hline
\end{tabular}

In the winter and rainy season kidnapping of children be increased. But data shows that the number of kidnapping children is increasing and sometimes decreasing frighteningly day by day in Sylhet.

\section{Raped Girl}

Section 375 of Bangladesh Penal Code, 1860 provides that "a man is said to commit 'rape' who except in the case hereinafter excepted, has sexual 
intercourse with a woman under circumstances falling under any of the five following descriptions firstly, against her will, secondly, without her consent, thirdly, with her consent, has been obtained by putting her in fear of death or of hurt, fourthly, with her consent, when the man knows that he is not her husband, and that her consent is given because she believes that he is another man to whom she is or believes herself to be lawfully married, fifthly, with or without her consent, when she is under fourteen years of age 7 . Because of gender discrimination girls are often victim from her birth (Choudhury, 2011; Ferdousi, 2015). Girls may be raped by friends, teachers, cousins, strangers and sometimes family members. "Girls are at higher risk than boys for infrastructure, sexual abuse, educational and nutritional neglect, and forced prostitution. The raped girl has to undergo severe mental and social constraints. At night, girls are afraid to visit the markets and other places in that area. Because, they feel lack of security.

Raped girls in Moulvibazer, Habigonj, Sunamgonj, Sylhet and Sylhet Metropolitan Area (2013August 2018) (Source: Victim Support Centre kotwali Model Police Station S M P Sylhet).

\begin{tabular}{|c|c|}
\hline Year & Raped Girl \\
\hline 2013 & 2 \\
\hline 2014 & 13 \\
\hline 2015 & 13 \\
\hline 2016 & 17 \\
\hline 2017 & 10 \\
\hline 2018 & 7 \\
\hline Total & 62 \\
\hline
\end{tabular}

\section{Probation Officer in Sylhet Metropolitan Area}

The Children Act, 2013 provides that the Government shall appoint one or more Probation Officers in every district upazila and metropolitan area. Section 6 lays down provision relating to duties and responsibilities of a Probation Officer. Section 5 and 6 has very good implementation in Sylhet Metropolitan Area. In that area Probation Officer Mr. Tomir Ahmed Chowdhury always goes to the Police Station if a child whether in contact with the law or in conflict with the law, is brought or otherwise comes to the Police Station and if it is possible to undertake diversion or bail the Probation Officer to do so for protecting the best interest of the child. The Probation Officer in that area always stays or present during the trial of a child. If any child in conflict with the law is sent to any Child Development UniversePG I www.universepg.com
Centre or any certified Institute the Probation Officer maintain a separate file for each child. That the Officer also works for diversion and alternative care for the children. The Probation Officer performs all duties mentioned in that Act.

\section{Child Affairs Police Officer Desk in Sylhet Met- ropolitan Area}

The Ministry of Home Affairs shall set up a Child Affairs Desk in every police station and the officer of this Child Affairs Desk shall not be below the rank of Sub -Inspector (Section -13). Sylhet Metropolitan Area has 6 (six) Police Station. Namely -

1) Kotwali Model Police Station;

2) Jalalabad Police Station;

3) Airport Police Station;

4) Moglabazar Police Station

5) South Surma Police Station

6) Shah Poran (R.) Police Station.

All of these Police Stations have existence of the Child Affairs Police Desk .The Police Officer of the Child Affairs Desk not below the rank of Sub Inspector and he is called Child Affairs Police Officer. Some Police Station of this area has female Sub Inspector for discharging responsibilities of the 'Child Affairs Desk That the section 13 has very good implementation all of this mentioned police station in Sylhet Metropolitan Area. The Child Affairs Police Officer shall discharge the following duties and functions, namely:

1) To maintain separate files and registers for the case concerning children;

2) If any child comes or is brought to the police station to inform the probation officer, family member;

3) If it is not possible to undertake diversion or release the child on bail due to any reason, to arrange for placement in a safe home before pro ducing the child in the court for the first time;

4) At every month to send all information of child related cases in prescribed from to the probation officer and to the police head-quarters through superintendent of police and, where applicable, to the District Legal Aid Committee and also perform other duties which is mentioned under section 14.

5) But the Child Affairs Police Officer at every month cannot send all information of child related cases in prescribed from to the Probation Officer regularly in that area. Child Affairs 
Police Officer deals child related cases with others duties of the Police Station that the reason may obstacle in case of implementation of section 14 (f) in Sylhet Metropolitan Area. All of the Police Station of this Sylhet Metropolitan Area no charge sheet shall be submitted accusing a child jointly with any adult offender for any offence.

\section{Sylhet Metropolitan Children's Court}

Section 16 of this Act provides that there shall be at least one court to be called the Children's Court in every district headquarter and in every metropolitan area. The Department of Law and Justice in consultation with the Supreme Court shall, by notification in the official Gazette, declare one or more courts of Additional Sessions Judge in every District and metropolitan area as the Children's Court. This section 16 of this Act has implementation in this Sylhet Metropolitan Area. Metropolitan Children's Court was established in 2014. The Additional Metropolitan Sessions Judge discharge such function as a Judge of the Metropolitan Children's Court. Metropolitan Children's Court sits on Monday and Wednesday only (2) days per week. A child in conflict with the law or a child in contact with the law is involved in any case the Children's Court shall have the exclusive jurisdiction to try the case. If any child is involved in a case together with any adult, the Chil dren's Court take evidence of the Child and adult sep arately on the basis of separate charge sheet under section 15. The Children's Court exercises the powers of a court of sessions under the code of Crim inal Procedure and Jurisdictions of Civil court in respect of issuing summons, summoning witnesses and ensuring their appearance, producing documents or material and receiving evidence on oath. If a child in conflict with the law, who has not been released on bail from the police station, is produced before that court, the Metropolitan Children's Court may release him on bail or pass an order to detain him in a safe home or child development centre. Lawyer, member of the police or other employees of the Court shall not wear their professional or official uniform in the courtroom during trial of a child in a Metropolitan Children's Court, Sylhet. That no child shall be sentenced to death, imprisonment for life. But where a child is found guilty of an offence punishable with death or imprisonment for life, that the Children's Court may order him to be detained for a period not exceeding 10 years but not less than 3 years in a Child Development Centre and other cases that the court may order him to be detained in a Child Development Centre for a period not exceeding 3 years.

Metropolitan Children's Court, Sylhet (Data 2013- August 2018)

\begin{tabular}{|c|c|c|c|c|}
\hline \multirow[t]{2}{*}{ Year } & \multirow[t]{2}{*}{ Number of Case } & \multicolumn{2}{|l|}{ Disposal Case } & \multirow[t]{2}{*}{ Pending Case } \\
\hline & & Monthly & Yearly & \\
\hline 2013 & $\mathrm{X}$ & $\mathrm{X}$ & $\mathrm{X}$ & \multirow{7}{*}{305} \\
\hline 2014 & 39 & $\mathrm{X}$ & $\mathrm{X}$ & \\
\hline 2015 & 30 & April $=2$, August $=3$, September $=1$ & 6 & \\
\hline 2016 & 151 & April $=3$, September $=1$ & 4 & \\
\hline 2017 & 83 & January $=1$ February $=2$ & 3 & \\
\hline August, 2018 & 80 & 4,11 & 15 & \\
\hline Total & 383 & 28 & & \\
\hline
\end{tabular}

It is not possible to complete the trial of a case within the mentioned period (360 days) of the Children Act, 2013. The Children Act, 2013 does not say anything about the permanent judges of the Children Court. Sylhet Metropolitan Children's Court cannot complete trial within the mentioned time due to the lack of the permanent judge. So, the cases remain pending in that court.

\section{Disadvantaged children in Sylhet}

The Government may take necessary measures in the manner prescribed by rules for the purposes of ensuring special protection, care and development of the disadvantaged children. The Department shall ensure the institutional care through any of the following institutes in light of the policy formulated by the Government in this behalf for the disadvantaged children for whom the parental care or non - intuittional care under sub - sections(2) and (3) of section 84 may not be ensured, namely:

a. Government children homes (Sharkari Shishu paribar);

b. Baby homes (Chotomoni Nibash);

c. Training and rehabilitation centers for the destitute Children; 
d. Government shelter homes; and

e. Other institutes to be determined by the Government (Section 85).

Sylhet has 4 Districts namely Moulvibazer, Hobigonj, Sunamgonj and one Metropolitan Area namely
Sylhet Metropolitan Area. For the best interest of the child the Government established some institutions care for the disadvantaged children. In that area there has been good implementation of the Section 84, 85, 86 and 89 .

\section{Number of Disadvantaged children in Sylhet Division 2021}

\begin{tabular}{|c|c|c|}
\hline Institutions Name & Number of Child & Total Seats \\
\hline Sharkari Shishu Paribar (Boy) & 145 & 165 \\
\hline Chotomoni Nibash & 44 & \\
Safe Home & 35 & 641 \\
\hline Shekh Rasel Shishi Training and Rehabilitation centre & 639 & 90 \\
\hline Sharkari Shishu Paribar (Girl) & 90 & \\
\hline Total & 953 & \\
\hline
\end{tabular}

Sharkari Shishu Paribar (Boy) was established in 1958 at Bagbari in Sylhet. In 1958 to August 2018 total 1568 children admitted and 1423 left this institution. At present there are145 children. This institution ensured the children food, shelter, education, hospitality, dresses and some others facilities. There are also 10 seats for old persons in this institution. At present, 4 old persons are living there. Sharkari Shishu Paribar (Boy) was established for boys but now that institution is used also taking old persons which may affect boy's lifestyle and daily necessities. Safe Home (Girl) was established in November, 2002 at Bagbari in Sylhet. In 2002 to August 2018 there had 1935 children. At present, there are 35 and total 1904 children left this institution. These institutions give the security and provides all basic necessities for the children. Chotomoni Nibash was instituted in 2003 at Bagbari in Sylhet. In 2003 to 7th October, 2018 total 252 children's admitted.

At present, there are 44 children. This institution tries to provide all of the basic necessities of the children. Shekh Rasel Training and Rehabilitation Centre were established in 2012. Total 643 children admitted in 2012 to August 2018.Total released form that institutions are 522. Now there aretotal 93 children and total seat 100. Sharkari Shishu Paribar (Girl) was established 1972 in Sylhet. In 1972 to August 2021 total released girls are 597. At present, this institution has 90 seats and 90 girls. This institution provides all of the basic necessities and special technical training for the girls.

\section{Establishment of Metropolitan Child Welfare Board}

The Children Act, 2013 lays down the provisions relating to National Child Welfare Board and its fun- ctions. District Welfare Board and its functions and Upazila Child Welfare Board and its functions under section 7, 8 and 9 but in the Act no provision is mentioned about the Metropolitan Child Welfare Board and its functions. If Metropolitan Child Welfare Board were established it may discharge the following duties and functions - to visit the Child Development Centre or, as the case may be, the certified Institute or any other Institute for children, if any, and to inspect the jail and to supervise, coordinate, monitor and evaluate the activities undertaken by those Institute; to determine the method of necessary alternative care for the disadvantaged children and for children in contact with the law and, where applicable, send them for alternative care and to analyses the data and information of the child under such care; to discuss on the information provided by the Child Development Centres, certified Institutes or, in case of necessity jail authority and to take necessary measures or initiatives for the welfare of the children; and to take such other measures as may be necessary to discharge the aforesaid duties and functions. This Board needs to participate the local Government (City Corporation) representative as an advisor. If without establishing Metropolitan Child Welfare Board, establishment of National, District and Upazila Chlid Welfare Board by this Act will be discrimination. So, it is very important to establish Metropolitan Child Welfare Board in all the Metropolitan Area in Bangladesh including Sylhet Metropolitan Area.

\section{Establishment of the Metropolitan Child Deve- lopment Centre}

Child development centre means an institution which is working for development of child where child gets 
care and support. Section 59 lays down that the Government shall establish and maintain required number of Child Development Centres, based on gender disaggregation for accommodation, correction, and development of the children ordered to be detained in the judicial proceedings and for the children under trial. In Sylhet Metropolitan area no child development centre is established. In Bangladesh, there are only 3 child development centres. Name of the child development centres in Bangladesh are mentioned below that 1) Child Development Centre (boy) Tongi, Gazipur; 2) Child Development Centre (Girl) Konabari, Gazipur; 3) Jessore Child Development Centre (Boy). When a child is in custody in conflict with law, for ensuring his/her accommodation, correction, development and maintenance it are very important to establish this child development centre in Sylhet Metropolitan Area. For the best protection of child interest and implementation of section 59 in that mentioned area it is necessary to establish this child development centre.

\section{Findings of the study}

1) That the Act lies down provisions relating National, District and Upazila Chlid Welfare Board. But that the Act does not lay down any provision relating to Metropolitan Child Welfare Board. For that reason, the mentioned Act makes discrimination among the Metropolitan Area, District and Upazila.

2) That the Act mentioned that advisor for District and Upazila Child Welfare Board will be nominated by the representative of the people. But that the Act is silent about the participation of the City Corporation representative. It makes discrimination among the local Government (City Corporation, District and Upazila).

3) That the Act does not lay down any provision for appointment of permanent Judge for the Children's Court.

4) That the Act under section 32 mentioned that the Children's Court shall complete trial within 360 (three hundred and sixty) days from the day of the child appearance before it. It may extend additional 60 (sixty) days on reasonable ground. But in practically it is not possible to complete trial within the mentioned period of this Act.

5) That the Act does not make any obligatory provision for all the concerned persons or institutions that they will provide child related in- formation to the Legal Researchers which will be beneficial for the child.

6) That section 59 of the Act says about the Child Development Centre but where it shall be established it is not mentioned.

7) That the Act is named as the Children Act, 2013 but that the Act does not say anything specifically about the disabled children.

8) That the Act does not mention the consequence if the Child Affairs Police Officer at every month does not send all information of child related cases in prescribed from to the Probation Officer and to the Police Head Quarters through Superintendent of Police and, where applicable, to the District Legal Aid Committee.

\section{Suggestions}

a) The Child Affairs Police Officer sends all information of child related cases in prescribed form to the probation officer at every month regularly.

b) The Child Affairs Police Officer shall not perform any other duties of the Police Station accept child affairs.

c) It is important to amend this Act and include the provisions relating to establishment of the Metropolitan Child Welfare Board and this Board will ensure participation of the local Government (City Corporation) representative who acts as an advisor of this Board.

d) Section 59 of the Act need to be amended and the territory for establishment of the Child Development Centre should be fixed.

e) The Government shall appoint permanent Judges for the Metropolitan Children's Court, Sylhet.

f) This Act need to add provisions relating to disabled child.

g) Special training on the Children Act, 2013 and UNCRC must be provided to Probation officer and Child Affairs Police Officer.

h) If any researcher does any research on the Children Act, 2013 and on other topics relating to children the Probation Officer, Judge of the Children Court and specially the Child Affairs Police Officer need to cooperate him by providing essential information and data about that said topic.

i) The Judge of the Metropolitan Children's Court should conclude trial within the said period in this Act. 
a. All classes of people including concerned persons under the Act should be aware for protecting the best interest of the child for the better implementation of the Children Act, 2013 in Sylhet Metropolitan area.

\section{CONCLUSION:}

The Government passed the Children Act, 2013 for protecting the best interest of the child. The Children Act, 2013 has good application in Sylhet Metropolitan area but for better implementation of this Act in that mentioned area, the Government should take cognizance of the recommendations of this research. If the government taking to consideration the above mentioned recommendations it will be helpful to establish rule of law in that mentioned area and Bangladesh. It is time to take proper actions against which are obstacle for implementation of that Act in that area. The Government and other concerned institutions mentioned in that Act should organize public awareness for welfare of the child. Because, Children are the future generation of the nation.

\section{ACKNOWLEDGEMENT:}

The authors would like to express gratitude to the Sharkari Shishu Paribar, Chotomoni Nibash, Shekh Rasel Shishu Training and Rehabilitation centre, Sylhet for their genial support by providing data in completion of the research work.

\section{CONFLICTS OF INTEREST:}

The authors declared no potential conflicts of the interest with respect to the research work.

\section{REFERENCES:}

1) Ali, I. (2013). The Children Act 2013, A Commentary by Justice Imman Ali, BLAST and PRI.

https://www.refworld.org/cgibin/texis/vtx/rwmai n/opendocpdf.pdf?reldoc $=\mathrm{y} \&$ docid $=542 \mathrm{e} 5 \mathrm{e} 2 \mathrm{c} 4$

2) Ashrafuzzaman, (2014). Special Report: Inexistent Rule of Law in Bangladesh, Asian Legal Resource Centre, Hong Kong, 13(2). www.article2.org/mainfile.php/1302/479

3) Banks, C. (2007). The Discourse of Children's Rights in Bangladesh: International Norms and Local Definitions, 15 Int'l J. Child. Rts. 391 https://heinonline.org/HOL/LandingPage?handle =hein.journals/intjchrb15\&div=28\&id=\&page

4) Blanchet, T. (2001) Child Work in a Bihari Camp and in the Benarasi Sari Industry of
Mirpur. Save the Children Sweden Bangladesh: Dhaka.

https://www.researchgate.net/publication/299357 245 Mirpur Benarasi Palli of Bangladesh Liv ing_and_Livelihood_of_Weavers

5) Choudhury, R.K. (2011). The status of unserved children in education Working Children in Bangladesh, Campaign for Popular Education (CAMPE).

6) Ehsan, K. (2001). "Children and Education", in Shishu Adhikar Sangjog (ed.), Child Rights: Reality and Challenges (Dhaka, Bangladesh: British Council).

http://jswhr.com/journals/jswhr/Vol_2_No_1_M arch 2014/12.pdf

7) Ferdousi, N. (2014). Best Practice in the Institutional Treatment of Juvenile Delinquents in Bangladesh: An Appraisal, 19, The Chittagong University Journal of Law, 75.

https://www.bildbd.com/index.php/blj/article/do wnload/108/83

8) Ferdousi, N. (2015). Deprive Children in the Development Centers, The Daily Star, and 27 April, 2015.

https://www.thedailystar.net/law-our-rights/de prived-children-the-development-centers-78343

9) Islam, M. (2012). Constitutional law of Bangladesh, 3rd ed.; Mullick Brothers, 42 Bangla bazar, Dhaka, Bangladesh.

10) Islam MN. (2020). The impact of human rights violation concerning the status of women and children in Bangladesh: a critical review, Br. J. Arts Humanit., 2(1), 1-13. https://doi.org/10.34104/bjah.02001013

11) Islam, M.T. (2015). Juvenile Delinquency in Bangladesh: Identifying the Causes with Reference to Some Case Studies\| 2 Law Journal Bangladesh.

http://www.lawjournalbd.com/2015/02/juveniledelinquency-in-bangladesh-identifying-thecauses-with-reference-to-some-case-studies/

12) Mamun, R.; Mondal, N.I.; Islam, R. and Kabir, M. (2008). Impact of Some Key Factors on Health Complication of the Child Laborers during Work: A Study on Rangpur, Bangladesh, Pakistan Journal of Social Sciences, 5(3), 262-267.

https://www.researchgate.net/publication/261995 $\underline{548}$ 
13) Mohajan, H. (2014). Child Rights in Bangladesh, Journal of Social Welfare and Human Rights, 2(1), pp. 207-238.

https://mpra.ub.uni-muenchen.de/id/eprint/58424

14) Pare, M. (2003). Why has Street Children Disappeared? The Role of International $\mathrm{Hu}$ man Rights Law in Protecting Vulnerable Groups, The International Journal of Children's Rights, 11(1), 1-32.

http://dx.doi.org/10.1163/092755603322384001
15) WHITE, S.C. (2002). From the Politics of Poverty to the Politics of Identity? Child Rights and Working Children in Bangladesh. Journal of International Development, 14, 725-735.

https://onlinelibrary.wiley.com/doi/epdf/10.1002 /jid.919

Citation: Islam MJ, Arifuzzaman M, and Khan JA. (2022). Practical scenario of implementation of the children act, 2013 in Sylhet metropolitan area and rule of law, Br. J. Arts Humanit., 4(1), 23-31. https://doi.org/10.34104/bjah.022023031 